\title{
The Relationship of Dapsone (DDS) Therapy to Erythema Nodosum Leprosum Is it Direct or Indirect?
}

\author{
M. F. R. WATERS AND H. S. HELMY* \\ Leprosy Research Unit, National Leprosy Control Centre. \\ Sungei Buloh, Selangor, Malaysia
}

\begin{abstract}
A double-blind, internally-controlled clinical trial is reported of the effect of dapsone on the severity of erythema nodosum leprosum (ENL) in 17 sulphoneresistant lepromatous patients, 16 of whom were suffering from ENL of varying severity. During the 10 weeks of the trial, alternative anti-leprosy treatment was continued unchanged. Dapsone, $100 \mathrm{mg}$ daily in a coloured capsule, was prescribed for 14 consecutive days between the third and seventh weeks, the timing being allocated by random distribution, and on the remaining 56 days an identical placebo capsule was given. The clinical severity of the ENL was measured by a number of parameters, and the intake of all reaction-suppressing drugs was recorded. No evidence was obtained that dapsone either immediately or after an interval, exacerbated or precipitated episodes of ENL. It is concluded that dapsone has no direct ENL-stimulating action per se, but that ENL results indirectly, consequent on the drug's chemotherapeutic activity against Mycobacterium leprae.
\end{abstract}

It is universally agreed that the introduction of the sulphone group of drugs resulted in a marked increase in the incidence of erythema nodosum leprosum (lepromatous lepra reaction, ENL). The commencing of effective treatment sooner or later precipitates ENL in many lepromatous patients. However, the precise mechanism whereby dapsone (DDS) and other proven anti-leprosy drugs predispose patients to, or initiate attacks of, ENL has been little investigated. Two theories have been propounded. The first considered that the relationship was an indirect one; effective chemotherapy results in the death of leprosy bacilli, and subsequently the products of bacterial disintegration are released into the bloodstream or tissues, and cause ENL (Mitsuda, 1953; Pepler et al., 1955). This theory has been supported by studies on the morphology of Mycobacterium leprae (Ridley, 1960; Pettit and Waters, 1967). The second theory, or rather group of theories, as there are a number of not very well defined variants, considers that dapsone acts directly on the tissues, and that as a corollary the tissue effect is closely related to the dosage of dapsone employed. Thus Jopling

* Present address: Ministry of Health, Cairo, Egypt

Received for publication 6 J une 1974 
(1964) stated that a patient suffering from ENL with no known precipitating cause, can be told that, "His tissues have been destroying the leprosy bacilli too rapidly and it is necessary to proceed at a slower tempo; he will then appreciate the reason for reducing the dosage of anti-leprosy drug." Cochrane (1967) suggested that dapsone does not act directly on the leprosy bacillus, but through cell lysosomes; and warned that dapsone in full dosage might push very active lepromatous patients into reactive phases.

It therefore seemed important to us, not only for theoretical but also for practical reasons related to patient management, to investigate whether there was any evidence of a direct relationship between dapsone and ENL divorced from its chemotherapeutic activity. Until recently, this was not possible. However, over the past decade, more than 100 proven sulphone-resistant patients have been detected at the Leprosy Research Unit, Sungei Buloh. Therefore, a double-blind, internally-controlled study was devised to investigate the effect of dapsone on the severity of ENL in a group of sulphone-resistant patients, in whom it was assumed that the drug could have no chemotherapeutic action.

\section{Patients and Methods}

The design of the trial was based on the methods developed at the Leprosy Research Unit for testing the effect of drugs against established ENL (Pearson and Vedagiri, 1969; Waters, 1971a; Helmy et al., 1971; Pearson and Helmy, 1973).

Twenty patients were selected from among those regularly attending the Research Unit; three were in hospital wards, 16 were living in quarters within and one lived just outside the hospital grounds. Seventeen were male and three were female; all except one were Chinese. All 20 were suffering clinically from sulphone resistant lepromatous leprosy, and in the 18 in whom inoculation studies were successful, dapsone resistance was confirmed by drug sensitivity testing in mice. All had received effective alternative treatment with rifampicin, rifampicin plus thiambutosine, clofazime, or clofazimine plus rifampicin, for at least three months (range 3-51, average 16 months). The patients were smear positive, with an average bacterial index (BI) of 4.0 (range 2.2 to 5.0); and the morphological index (MI) was 0. All patients gave a history of ENL, and 19 were suffering from reactions of varying severity at the start of the trial, although in half the ENL was mild and intermittent.

The clinical diagnoses of ENL and of lepromatous leprosy were histologically confirmed. Before admission to the trial, patients underwent a complete clinical examination, including assessment of ENL; blood count and urinalysis were performed, and the urine was checked for dapsone content. Skin smears were taken, unless they had been examined within the previous three months, and lepromin and tuberculin skin tests were carried out, unless they had been performed within the previous year.

\section{Design of the Trial}

The trial lasted ten weeks. Throughout this time, patients continued on their anti-leprosy treatment in unchanged dosage, including the four receiving clofazimine (two on $200 \mathrm{mg}$ daily, and two on $100 \mathrm{mg}$ twice or thrice weekly respectively). Dapsone was given in the form of a single, coloured capsule containing $100 \mathrm{mg}$ of drug, daily for 14 days, commencing either on day 15,22 , 
29 or 36. Allocation was by random distribution using the sealed envelope technique (Waters et al., 1967), and five patients commenced dapsone on each of the four possible days. The doctor in clinical charge (H.S.H.) was kept in ignorance of the dates until the trial was completed and the results tabulated. For the remaining 56 days of the trial, each patient received one placebo capsule, identical with the dapsone capsule, daily. Therefore the double-blind trial was divided into three periods as follows:

Pericd 1-Initial control period of at least two weeks' duration (range 2-6)-one placebo capsule daily.

Period 2-Dapsone period of two weeks-100 mg dapsone daily.

Period 3-Final control period of at least three weeks' duration (range 3-6)-one placebo capsule daily.

During all periods of the trial, the patients attended the Research Unit twice weekly at about 2 p.m., to have their temperatures taken, to undergo clinical examination, and to swallow (and be seen to swallow) the appropriate day's capsule. The next two, or three, days' capsules were issued to the patients to take in their quarters. Each patient was examined by the same doctor throughout, who recorded the severity of the ENL on a sheet specially prepared for each day (without reference to past records), noting the number of paracetamol, prednisolone and thalidomide tablets, clofazimine capsules and stibophen and corticotrophin injections consumed or received since his or her last visit. Regularly every two weeks urine was tested for the presence of dapsone, and white blood cell and differential counts were performed. At the end of the trial period, the complete clinical examination was repeated.

Although all clinical examinations were carried out blind by a single doctor (H.S.H.), as a check on his scoring each patient was examined by an independent clinical assessor before admission to the trial and, at a time unbeknown to him, during the second week of dapsone therapy. Throughout the trial, the doctor in clinical charge was free to prescribe anti-reaction treatment as he considered indicated by the condition of each individual patient.

\section{Meth ods of Scoring,}

On each examination the severity of a patient's ENL was categorized under seven headings, listed and scored according to Table 1. The latter also gives the method of scoring (allocation of numerical values) of the two objective assessments, namely the temperature and the white blood count. With experience gained from our previous trials it is considered that the subjective but important assessments of ENL severity and the pattern of prescribing anti-reaction treatment were consistent and reproducible so that meaningful comparisons could be made.

In the current trial, no attempt was made to equate the score of one clinical feature with another. Rather, the individual and group scores for each parameter have been totalled for each week (centred around the fortnight in which dapsone was administered) to assess if dapsone increased, decreased or had no effect on the severity of ENL in these specially selected patients. The scores have also been compared with the totals of the different anti-reaction treatments prescribed and taken, as increased effective treatment should result in decreased clinical severity of ENL if no absolute change in severity has occurred and vice versa. Similarly, alterations in reaction severity should be reflected either in corresponding 
TABLE 1

Clinical grading of ENL and scores allotted for different parameters on each twice-weekly examination.

\begin{tabular}{|c|c|c|c|c|c|c|c|c|c|}
\hline Score & $\begin{array}{l}\text { ENL (Skin } \\
\text { Number }\end{array}$ & $\begin{array}{l}\text { Lesions } \\
\text { Activity }\end{array}$ & $\begin{array}{l}\text { Nerve } \\
\text { involvement }\end{array}$ & $\begin{array}{l}\text { Lymph } \\
\text { nodes }\end{array}$ & Eyes & Test es & Arthrit is & $\begin{array}{l}\text { Maximum } \\
\text { temperature } \\
\text { recorded }\end{array}$ & $\begin{array}{l}\text { Total white } \\
\text { blood cell } \\
\text { count }^{a}\end{array}$ \\
\hline 0 & None & - & None & $\begin{array}{l}\text { Not } \\
\text { enlarged }\end{array}$ & $\begin{array}{l}\text { Not } \\
\text { inflamed }\end{array}$ & $\begin{array}{l}\text { No } \\
\text { orchit is }\end{array}$ & $\begin{array}{l}\text { No ENL } \\
\text { arthritis }\end{array}$ & Below $99^{\circ} \mathrm{F}$ & $0-9900$ \\
\hline 1 & Few & Mild & 1 tender & $\begin{array}{l}\text { Enlarged, } \\
\text { none } \\
\text { tender }\end{array}$ & $\begin{array}{l}\text { Conjunc- } \\
\text { tivitis } \\
\text { or iritis } \\
\text { present }\end{array}$ & $\begin{array}{l}\text { Orchitis } \\
\text { present }\end{array}$ & $\begin{array}{l}\text { ENL } \\
\text { arthrit is } \\
\text { present }\end{array}$ & $99^{\circ}-98^{8}$ & $\begin{array}{r}10,000- \\
13,900\end{array}$ \\
\hline 2 & $\begin{array}{l}\text { Moderate } \\
\text { number }\end{array}$ & $\begin{array}{l}\text { Moderately } \\
\text { active }\end{array}$ & $\begin{array}{l}\text { More than } 1 \\
\text { tender }\end{array}$ & $\begin{array}{l}\text { Enlarged, } \\
\text { one or } \\
\text { more } \\
\text { tender }\end{array}$ & - & - & - & $100^{\circ}-100^{8}$ & $\begin{array}{l}14,000- \\
17,900\end{array}$ \\
\hline 3 & Many & - & $\begin{array}{l}1 \text { nerve } \\
\text { painful }\end{array}$ & - & - & - & - & $\begin{array}{l}101^{\circ} \text { or } \\
\text { over }\end{array}$ & $\begin{array}{l}18,000 \text { or } \\
\text { more }\end{array}$ \\
\hline 4 & - & $\begin{array}{l}\text { Very active, } \\
\text { some ulcer- } \\
\text { ating and/or } \\
\text { forming } \\
\text { pustules }\end{array}$ & $\begin{array}{l}\text { More than } \\
1 \text { painful }\end{array}$ & - & - & - & - & - & - \\
\hline
\end{tabular}

$a_{\text {White blood cell count performed every fort night. }}$ 
alterations in observed clinical severity, or in appropriate changes in total treatment prescribed, or both.

\section{Results}

Although all 20 patients completed the trial, three have been omitted from the analyses, two because their urine failed to contain dapsone when it should, and one because his urine contained dapsone when the drug was not being prescribed.

In the remaining 17 patients, one (who had received only five months effective treatment for sulphone-resistant leprosy) did not suffer from ENL throughout the trial, although variable non-tender enlargement of her lymph nodes was recorded, and was considered to be a prodromal sign of ENL, which recurred shortly afterwards. A study of the individual results of the 16 patients suffering from ENL reveals only minor variations in reaction severity, consistent with the known natural variations occurring in ENL reactions. Table 2 gives the overall results (total weekly scores, i.e. aggregate of both twice-weekly examinations) for the 17 patients for the two weeks before, two weeks of, and the three weeks immediately succeeding the giving of daily dapsone; the table includes the scores

TABLE 2

Effect of dapsone, $100 \mathrm{mg}$ daily for two weeks on the clinical severity of ENL in 17 sulphone-resistant lepromatous patients-total weekly scores for the two weeks immediately before, the three weeks following and the fortnight of dapsone administration

\begin{tabular}{|c|c|c|c|c|c|c|c|}
\hline & \multicolumn{2}{|c|}{$\begin{array}{c}\text { Before dapsone } \\
\text { (weeks) }\end{array}$} & \multicolumn{2}{|c|}{$\begin{array}{c}\text { Dapsone period } \\
\text { (100 mg daily) } \\
\text { (weeks) }\end{array}$} & \multicolumn{3}{|c|}{$\begin{array}{l}\text { After dapsone } \\
\text { (weeks) }\end{array}$} \\
\hline & 2 & 1 & 1 & 2 & 1 & 2 & 3 \\
\hline $\begin{array}{l}\text { ENL skin lesions: } \\
\text { (a) number } \\
\text { (b) activity }\end{array}$ & $\begin{array}{l}22 \\
18\end{array}$ & $\begin{array}{l}26 \\
21\end{array}$ & $\begin{array}{l}21 \\
16\end{array}$ & $\begin{array}{l}17 \\
12\end{array}$ & $\begin{array}{l}19 \\
17\end{array}$ & $\begin{array}{l}25 \\
18\end{array}$ & $\begin{array}{l}21 \\
21\end{array}$ \\
\hline Nerves & 14 & 7 & 14 & 21 & 16 & 13 & 13 \\
\hline Lymph nodes & 14 & 16 & 14 & 12 & 12 & 16 & 20 \\
\hline Eyes $^{a}$ & 2 & 2 & 2 & 1 & 1 & 1 & 0 \\
\hline Testis $^{b}$ & 0 & 0 & 0 & 0 & 0 & 1 & 0 \\
\hline Arthritis & 1 & 0 & 1 & () & 0 & 0 & 0 \\
\hline Temperature & 0 & 2 & 0 & $4^{d}$ & 3 & $6^{d}$ & 2 \\
\hline White blood count ${ }^{c}$ & & 5 & & $8^{d}$ & & $6^{d}$ & \\
\hline
\end{tabular}

${ }^{a}$ Based on 16 patients, as one was blind from past iritis.

$b$ Based on 14 patients ( 3 were female).

${ }^{c}$ Fortnightly examinations.

${ }^{d}$ These figures were influenced by factors additional to ENL (see text). 
of the seven measured individual clinical parameters of ENL severity, plus temperature and white blood count assessments. These results should be interpreted in conjunction with those of Table 3, which gives details of total anti-reaction treatment prescribed and taken each week during the same periods. Seven patients received only paracetamol and/or stibophen, eight required thalidomide with or without paracetamol and stibophen (two of these were also receiving clofazimine, in low dosage), and two received high dosage clofazimine, one also requiring daily prednisolone. In interpreting the paracetamol intake, allowance must be made for two patients whose dosage was temporarily increased, twice each, for reasons other than ENL, including two episodes of

TABLE 3

Effect of dapsone, $100 \mathrm{mg}$ daily for two weeks on the severity of ENL in 17 sulphone-resistant lepromatous patients-total weekly dosage of ENL-suppressing drugs given during the two weeks immediately before, the three weeks following, and the fortnight of dapsone administration.

\begin{tabular}{|c|c|c|c|c|c|c|c|}
\hline \multirow[t]{2}{*}{ ENL treatment } & \multicolumn{2}{|c|}{$\begin{array}{l}\text { Before dapsone } \\
\text { (weeks) }\end{array}$} & \multicolumn{2}{|c|}{$\begin{array}{l}\text { Dapsone period } \\
\text { (100 mg daily) } \\
\text { (weeks) }\end{array}$} & \multicolumn{3}{|c|}{$\begin{array}{l}\text { After dapsone } \\
\text { (weeks) }\end{array}$} \\
\hline & 2 & 1 & 1 & 2 & 1 & 2 & 3 \\
\hline $\begin{array}{l}\text { Thalid omide } \\
\text { (no. of } 100 \\
\text { mg tablets) }\end{array}$ & $62 \frac{1 / 2}{2}$ & 54 & 52 & $52 \frac{1}{2}$ & 54 & $45^{1 / 2}$ & 40 \\
\hline $\begin{array}{l}\text { Clofazimine } \\
\text { (no. of } 100 \\
\text { mg capsules) }\end{array}$ & 33 & 33 & 33 & 33 & 33 & 33 & 33 \\
\hline $\begin{array}{l}\text { Prednisolone }{ }^{a} \\
(\mathrm{mg})\end{array}$ & $52 \frac{1 / 2}{2}$ & $471 / 2$ & $371 / 2$ & $57^{1 / 2}$ & $52 \frac{1}{2}$ & $52^{1 / 2}$ & $52 \frac{1}{2}$ \\
\hline $\begin{array}{l}\text { Stibophen } \\
(\mathrm{ml})\end{array}$ & 14 & 16 & 6 & 8 & 10 & 4 & 4 \\
\hline $\begin{array}{l}\text { Paracetamol } \\
\text { (no. of } \\
\text { tablets) }\end{array}$ & 112 & 97 & 105 & 142 & 113 & 83 & 114 \\
\hline
\end{tabular}

${ }^{a}$ One patient only received prednisolone, and none corticotrophin during these seven weeks.

$b$ Parace tamol intake was influenced by factors additional to ENL (see text).

cellulitis, a mild virus infection and a painful biopsy site. It is concluded that in no patient did the ENL significantly worsen as a result of dapsone intake nor was ENL precipitated by dapsone in the one patient in the prodromal stage of reaction. This is confirmed by the results given in Tables 2 and 3, which reveal no evidence, either from the intake of reaction-suppressing drugs, or from the clinical severity of the ENL, of any increase in ENL severity, either during the two weeks of dapsone administration or in the immediately succeeding three weeks. 


\section{Discussion}

The 17 patients included in this trial showed a wide range of reaction severity. Six were suffering from mild ENL, and one from prodromal ENL, and they were easily controlled by analgesics and/or stibophen. Ten were more severe, eight requiring daily thalidomide and two clofazimine, in one case combined with daily prednisolone, to control adequately the clinical signs of reactions; even so, two patients experienced short episodes of ulcerating or pustular ENL during the trial. Therefore if dapsone possessed any direct ENL-stimulating effect, as opposed to its chemotherapeutic effect on $M y c o$. leprae, we could confidently have expected to be able to detect such an action in this group of sulphone-resistant patients. The trial was designed to include not only the abrupt starting of $100 \mathrm{mg}$ dapsone daily - a dose widely considered to be sufficient to precipitate or exacerbate ENL in many reaction-prone patients-but also a second control period of at least three weeks' duration. The latter enabled us to investigate any delayed dapsone effect, such as appeared to occur in the third and fourth weeks after restarting dapsone in sulphone-sensitive, moderately severe ENL patients (Pearson and Helmy, 1973). No immediate or delayed effect was detected. Therefore we conclude that dapsone produces or stimulates ENL in lepromatous patients only indirectly, as a consequence of the death of Myco. leprae resulting from the drug's effective chemotherapeutic action.

This conclusion is in keeping with recent studies on the aetiology of ENL, which has been shown to be an immune-complex disease, comparable to the Arthus phenomenon in experimental animals. Immunoglobulin (IgG) and complement have been demonstrated in ENL skin lesions (Wemambu et al., 1969; Waters et al., 1971), and immune complexes have been detected in lepromatous sera (Rojas-Espinosa et al., 1972), especially in those patients suffering from ENL (Moran et al., 1972; Gelber et al., 1973). Turk and his colleagues have suggested that the antigen moiety of the immune complex may be a soluble, cytoplasmic (not surface) mycobacterial antigen released from dead leprosy bacilli. Why some lepromatous patients remain free of ENL despite long periods of effective treatment, whereas others develop reactions of varying degrees of severity remains speculative; possibly only in a proportion of patients do such antigen-antibody ratios occur which result in the formation of immune complexes capable of producing ENL. Other techniques have been developed to enable further studies to be undertaken, both on the immune complexes themselves, and on the isolation and identification of the mycobacterial-antigen component, and their results are awaited with interest.

If the relationship between ENL and dapsone is an indirect one, dependent on the drug's chemotherapeutic activity, why, as a number of workers maintain, is there any correlation between dapsone dosage and the incidence and severity of reactions? In a series of papers, both Shepard and Rees and their respective colleagues have shown that the minimal effective dose (MED) of dapsone for mice infected with wild strains of Myco. leprae is $0.0001 \%$ DDS in the diet, and that this MED gives a dapsone serum concentration (minimal inhibitory concentration, MIC) in mice of the order of $0.01 \mu \mathrm{g} / \mathrm{ml}$ (see Ellard et al., 1971). Waters et al. (1968) reported that $1 \mathrm{mg}$ dapsone given daily by mouth to seven previously untreated lepromatous patients for 4.5 to six months resulted in a full normal clinical rate of response, with the smear MI falling to zero, or close to zero within 4.5 months. The one patient who elected to remain on $1 \mathrm{mg}$ dapsone daily for a 
prolonged period, subsequently developed ENL (Waters and Rees, in preparation). Serum concentrations in the seven patients averaged $0.018 \mu \mathrm{g} / \mathrm{ml}, 3 \mathrm{~h}$ after taking $1 \mathrm{mg}$ dapsone (Ellard et al., 1971). Therefore both from clinical proof, and by analogy with mice, as little as $1 \mathrm{mg}$ dapsone daily is above the MED and produces serum levels above the MIC in man. This in turn would suggest that any dose of dapsone from $1 \mathrm{mg}$ upwards, resulting as it does in death of leprosy bacilli, would predispose a drug-sensitive lepromatous patient to ENL. Furthermore the precise dose of dapsone prescribed, provided it was above the MED, should have little or no effect on the overall incidence or severity of the resulting reactions in a group of patients. In an admittedly uncontrolled study, we were unable to find any difference over the course of one year in the incidence or severity of ENL developing in two groups of previously untreated lepromatous patients, one receiving $50 \mathrm{mg}$ dapsone twice weekly by mouth, and the other $300 \mathrm{mg}$ dapsone twice weekly by injection (Waters, 1968). However, a number of other authors have maintained, also on apparently uncontrolled data, that in general the higher the dose of dapsone prescribed the higher the incidence of ENL. Some have reported that certain patients appear to have a "trigger" or "threshold" level of dapsone, and dosage above this level invariably leads to episodes of ENL. Moreover, it is authoritatively recommended, for example by the WHO Expert Committee on Leprosy, Third Report (1966), that treatment with dapsone should be suspended when signs of reaction develop, and that after these have subsided, the drug should only be restarted in small dosage. To settle the controversy, a prospective, controlled, preferably double-blind trial of the incidence and severity of ENL in groups of previously untreated lepromatous patients receiving different dosages (above the MED) of dapsone, would appear justified. But low dosage, like irregular dosage of dapsone, has recently been shown to result in an increased incidence of dapsone resistance (Jacobson, 1973; Meade et al., 1973). With the introduction of thalidomide and of clofazimine, we consider that ENL is of less danger to lepromatous patients than the possible development of sulphone resistance. Therefore the onus is on those who advocate low dosage dapsone as producing less ENL, to give scientific proof that their view is correct. For ourselves, we continue to advocate the maintenance of dapsone, in full, uninterrupted dosage, in the treatment of patients suffering from ENL (Waters, $1968,1971 b$ ), and the trial now reported gives further support to this view.

\section{Acknowledgements}

This trial was designed in collaboration with Dr R. J. W. Rees of the National Institute for Medical Research, London. We are grateful to Dr D. S. Ridley, Hospital for Tropical Diseases, London for the biopsy reports; to Dr M. K. Bhojwani, Director, National Leprosy Control Centre, Sungei Buloh, Malaysia, for the independent clinical assessments of patients in the trial; to the Malayan Pharmaceutical Factory Sdn. Bhd., for the generous gift of dapsone and placebo capsules used in the study; and to our staff and patients for their support and co-operation. One of us (H.S.H.) wishes to thank the Malaysian Ministry of Health for permission to publish. The Leprosy Research Unit, Sungei Buloh, is jointly sponsored by the Malaysian Ministry of Health, and the (British) Medical Research Council.

\section{References}

Cochrane, R. G. (1967). Medical treatment of leprosy. In Symposium on Leprosy, FebruaryMarch, 1965, (Eds N. H. Antia and D. K. Dastur). Bombay: J. J. Group of Hospitals, pp.135-141. 
Ellard, G. A., Gammon, P. T. Rees, R. J. W. and Waters, M. F. R. (1971). Studies on the determination of the minimal inhibitory concentration of $4,4^{\prime}$-diamino-diphenylsulphone (dapsone, DDS) against Mycobacterium leprae. Lepr. Rev. 42, 101-117.

Gelber, R. H., Epstein, V., Fasal, P. and Drutz, D. J. (1973). Erythema nodosum leprosum: an immune complex disease. In Abstr. Tenth Int. Leprosy Congr., Bergen, 1973, p.71. Reprinted in Int. J. Lepr. (1973), 41, 553-554.

Helmy, H. S., Pearson, J. M. H. and Waters, M. F. R. (1971). Treatment of moderately severe erythema nodosum leprosum with clofazimine-a controlled trial. Lepr. Rev. 42, $167-177$.

Jacobson, R. R. (1973). Sulphone-resistant leprosy: etiology, incidence and treatment in the United States. In Abstr. Tenth Int. Leprosy Congr., Bergen, 1973, p.202. Reprinted in Int. J. Lepr. (1973), 41, 684.

Jopling, W. H. (1964). Treatment of acute phases (reacticnal states) in lepromatous leprosy. In Leprosy in Theory and Practice, 2nd Ed. (Eds R. G. Cochrane and T. F. Davey). Bristol: John Wright and Sons, pp.418-421.

Meade, T. W., Pearson, J. M. H., Rees, R. J. W. and North, W. R. S. (1973). The epidemiology of sulphone-resistant leprosy. In Abstr. Tenth Int. Leprosy Congr., Bergen, 1973, p.202. Reprinted in Int. J. Lepr. (1973), 41, 684.

Mitsuda, K. (1953). On the etiology of erythema nodosum leprosum and the metabolism of leprosy bacilli. La Lepro 22, $111-112$.

Moran, C. J., Ryder, G., Turk, J. L. and Waters, M. F. R. (1972). Evidence for circulating immune complexes in lepromatous leprosy. Lancet 2, 572-573.

Pearson, J. M. H. and Helmy, H. S. (1973). The effect of stopping dapsone treatment for two months and then restarting it in full dosage in patients with moderately severe erythema nodosum leprosum. Lepr. Rev. 44, 75-82.

Pearson, J. M. H. and Vedagiri, M. (1969). Treatment of moderately severe erythema nodosum leprosum with thalidomide-a double-blind controlled trial. Lepr. Rev. 40, 111-116.

Pepler, W. J., Kooij, R. and Marshall, J. (1955). The histopathology of acute panniculitis nodosa (erythema nodosum leprosum). Int. J. Lepr. 23, 53-60.

Pettit, J. H. S. and Waters, M. F. R. (1967). The etiology of erythema nodosum leprosum. Int. J. Lepr. 35, 1-10.

Ridley, D. S. (1960). A bacteriologic study of erythema nodosum leprosum. Int. J. Lepr. 28, 254-266.

Rojas-Espinosa, O., Mendez-Navarrete, I. and Estrada-Parra, S. (1972). Presence of Clq-reactive immune complexes in patients with leprosy. Clin. exp. Immunol. 12, $215-223$.

Waters, M. F. R. (1968). The management of erythema nodosum leprosum with particular reference to continued dapsone therapy. Int. J. Lepr. 36, 638.

Waters, M. F. R. (1971a). An internally-controlled double-blind trial of thalidomide in severe erythema nodosum leprosum. Lepr. Rev. 42, 26-42.

Waters, M. F. R. (1971b). Treatment of reactions in leprosy. In Proc. Sixth Singapore-Malaysia Congr. Medicine, Singapore, 1971. Singapore: Academy of Medicine, vol. 6, pp.240-243.

Waters, M. F. R., Rees, R. J. W. and Ellard, G. A. (1968). Experimental and clinical st udies on the minimum inhibitory concentration (MIC) of dapsone (DDS) in leprosy. Int. J. Lepr. 36,651 .

Waters, M. F. R., Rees, R. J. W. and Sutherland, I. (1967). Chemotherapeutic trials in leprosy. 5. A study of methods used in clinical trials in lepromatous leprosy. Int. J. Lepr. 35, $311-335$.

Waters, M. F. R., Turk, J. L. and Wemambu, S. N. C. (1971). Mechanisms of reactions in leprosy. Int. J. Lepr. 39, 417-428.

Wemambu, S. N. C., Turk, J. L., Waters, M. F. R. and Rees, R. J. W. (1969). Erythema nodosum leprosum-a clinical manifestation of the Arthus phenomenon. Lancet 2, 933-935.

World Health Organization (1966). Expert committee on leprosy. Third report. WHO Tech. Rept. Series No. 319. 